\title{
Pentachlorophenol and the peripheral nervous sys a longitudinal study in exposed workers
}

\author{
G TRIEBIG, ${ }^{1}$ I CSUZDA, ${ }^{1}$ H J KREKELER, ${ }^{2}$ K H SCHALLER ${ }^{1}$
}

From the Institute of Occupational and Social Medicine and the Policlinic for Occupational Diseases, ${ }^{1}$ University of Erlangen/Nürnberg, D8520 Erlangen, and German Solvay-Werke Ltd, ${ }^{2}$ Rheinberg, West Germany

ABSTRACT A longitudinal study was performed to examine whether chronic occupational exposure to pentachlorophenol (PCP) or its compounds causes measurable alterations in the conduction velocity in peripheral nerves as an "adverse effect." In total, the results of nerve conduction velocit (NCV) determinations in 1980 and 1984 in 10 subjects ( 7 men, 3 women) who had been exposed fos an average of 16 years (range 4-24) were available. The concentrations of PCP in the air at the workplace varied between 0.3 and $180 \mu \mathrm{g} / \mathrm{m}^{3}$ and were thus below the maximum allowed concen马 tration (MAK value) of $500 \mu \mathrm{g} / \mathrm{m}^{3}$. The biological monitoring carried out showed the following results: PCP in the serum: 38-1270 $\mu \mathrm{g} / \mathrm{l}$; PCP in the urine: 8-1224 $\mu \mathrm{g} / 1$. Compared with the uppeif normal limits (PCP in the serum $150 \mu \mathrm{g} / \mathrm{l}, \mathrm{PCP}$ in the urine $60 \mu \mathrm{g} / \mathrm{l}$ ), distinct internal exposure to PCP has resulted in some of the employees. Determinations of the NCV of motor and sensory nerve fibres (ulnar, median, peroneal, and sural nerve) were always in the normal range. A significanథ difference in the NCV for the period 1980-4 could not be detected. In addition, the correlation analyses did not show any hints of "dose-effect relations." It is concluded that occupatiofase exposure to PCP over several years in the concentrations observed probably do not lead to âny adverse effects on the peripheral nervous system.

Pentachlorophenol (PCP) and its sodium salt are attaining increasing importance in industrial medicine and in environmental hygiene because of their wide distribution in preservatives and pesticides.

Investigations on the toxicity of PCP were carried out more than 40 years ago. ${ }^{1}$ In connection with the manufacture and processing of products containing PCP acute and chronic PCP intoxications have occasionally been observed. ${ }^{2-5} \mathrm{~A}$ fatal PCP intoxication has also recently been described. ${ }^{6}$ Despite comprehensive knowledge on its kinetics, metabolism, and toxicology, ${ }^{7-11}$ the question of possible peripheral neurotoxic effects in man has not yet been adequately clarified. ${ }^{12}$ In 1951 Baader and Bauer reported on neurological disorders in the context of a PCP intoxication. ${ }^{13}$

On the basis of its chemical structure, pentachlorophenol belongs to the group of polychlorinated aromatic hydrocarbons. In other compounds of this class such as hexachlorocyclohexane, ${ }^{14}$ poly-

Accepted 29 September 1986 chlorinated biphenyls, ${ }^{15}$ trichlorophenoxyacid, ${ }^{16}$ an $\frac{1}{1}$ chlorinated dioxins, ${ }^{17}$ neurotoxicity for man has bee? shown in some cases, so that such effects may also bê assumed as a hypothesis for PCP.

For this reason, we have examined by means of sensitive neurophysiological technique whetheo occupational exposure to PCP over several years caused adverse effects on the peripheral nervous sys: tem. ${ }^{18}$ Furthermore, the results could be compared with those of an earlier cross sectional investigation from $1980^{19}$ in order to detect any alterations that may have occurred during this time.

\section{Subject selection and methods}

The subjects investigated from a chemical company were 15 men and three women in 1980 and 12 mem and three women in 1984. A total of only 10 employes ees ( 7 men, 3 women) aged from 29 to 52 (median $41 \Phi$ were available for the longitudinal study. All employe ees had contact with PCP and PCP-containing sub stances for an average of 16 years (duration of employment 4-24 years). Three areas with differen? 
levels of PCP exposure could be defined on the basis of the production procedure:

(1) Production (high exposure).

(2) Filling (moderate exposure).

(3) Depot (low exposure).

The diagnostic procedure comprised the following single steps:

(1) Recording of the case history by means of a standardised questionnaire.

(2) Physical examination including initial neurological status.

(3) Determination of motor and sensory nerve conduction velocity of the ulnar, median, peroneal, and sural nerves.

(4) Biomonitoring (PCP in the serum, PCP in the urine).

PCP was determined in biological material using a sensitive gas chromatographic method as previously described. 2021

Furthermore, an "ambient air monitoring" with personal active sampling using impingers was carried out in five subjects. The neurophysiological findings were evaluated on the basis of our own reference values $^{22}$ and published data. ${ }^{23}$

\section{Results}

Table 1 shows data on the concentrations of PCP in the air at various workplaces in 1980 and 1984. The MAK value of $500 \mu \mathrm{g} / \mathrm{m}^{3}$, valid since 1978 , is not reached on average by a factor of 10 (production), 50 (filling), and 10 (depot). Furthermore, the results of measurements of air concentrations of tetrachlorophenols (TCP), $\quad \gamma$ hexachlorocyclohexane (lindan), and aldrin from 1977 and in some cases from 1984 were available. These chlorinated hydrocarbons could only be detected in traces in the range of $5 \mathrm{ppb}$ in 1977. The concentrations of TCP in the air varied between 1 and $291 \mu \mathrm{g} / \mathrm{m}^{3}$ in 1984 .

The results of biological monitoring are shown in table 2. The PCP concentrations in the serum vary

Table 1 Results of pentachlorophenol (PCP) in air at three different workplaces in 1980 and 1984 after stationary and personal sampling

\begin{tabular}{|c|c|c|}
\hline $\begin{array}{l}P C P \text { in air }\left(\mu \mathrm{g} / \mathrm{m}^{3}\right) \\
\text { (stationary sampling) }\end{array}$ & 1980 & 1984 \\
\hline $\begin{array}{l}\text { Production } \\
\text { Filling } \\
\text { Depot }\end{array}$ & $\begin{array}{l}2-50 \\
0 \cdot 3-8 \\
-\end{array}$ & $\begin{array}{l}2,2 \text { and } 134 \\
1 \text { and } 8 \\
29 \text { and } 180\end{array}$ \\
\hline $\begin{array}{l}\text { PCP in air } \\
\text { (personal sampling) } \\
\text { Production } \\
\text { Filling } \\
\text { Depot }\end{array}$ & - & $\frac{5,32 \text { and } 44}{13 \text { and } 67}$ \\
\hline
\end{tabular}

Table 2 Results of pentachlorophenol in serum and urine of 10 exposed workers in 1980 and 1984

\begin{tabular}{|c|c|c|}
\hline$P C P$ in serum $(\mu g / l)$ & 1980 & 1984 \\
\hline Production $(n=4)$ & $150,200,1100,1270$ & $\begin{array}{c}133,337,521 \\
1259\end{array}$ \\
\hline $\begin{array}{l}\text { Filling }(n=4 / 3) \\
\text { Depot }(n=2)\end{array}$ & $\begin{array}{l}80,100,110,460 \\
90,120\end{array}$ & $\begin{array}{l}105,124,463 \\
38,135\end{array}$ \\
\hline $\begin{array}{l}P C P \text { in urine }(\mu g / l) \\
\text { Production }(n=4) \\
\text { Filling }(n=4) \\
\text { Depot }(n=2)\end{array}$ & $\begin{array}{l}13,24,141,477 \\
13,19,587,1224 \\
78,557\end{array}$ & $\begin{array}{l}20,104,188,268 \\
4,12,12,55 \\
8,48\end{array}$ \\
\hline
\end{tabular}

between a minimum of $38 \mu \mathrm{g} / \mathrm{l}$ and a maximum of $1270 \mu \mathrm{g} / \mathrm{l}$ and show an increased PCP exposure compared with our upper normal limit of $150 \mu \mathrm{g} / \mathrm{l}^{2021}$

Lindan or TCP in serum varies between less than $1.5 \mu \mathrm{g} / \mathrm{l}$ and a maximum of $3 \mu \mathrm{g} / 1$ (upper normal limit less than $1.5 \mu \mathrm{g} / \mathrm{l})$ or less than $9 \mu \mathrm{g} / \mathrm{l}$ and a maximum of $156 \mu \mathrm{g} / 1$ respectively. In the urine the TCP concentrations range from less than $7 \mu \mathrm{g} / 1$ to $223 \mu \mathrm{g} / 1$ (normally undetectable).

An occupational exposure to other chemicals at the workplace known to have a peripheral neurotoxicity such as n-hexane, methyl-n-butylketone, and certain solvent mixtures could be ruled out from the history.

On the basis of the history and the laboratory results obtained in preventive medical examinations by one of us (HJK) there was no hint of a possible non-occupational risk of a polyneuropathy such as former neurological diseases, diabetes mellitus, excessive alcohol consumption (over $80 \mathrm{~g}$ of alcohol daily), or the intake of certain drugs.

Symptoms in the form of distal paresthaesias or muscular weakness, which might indicate a peripheral neuropathy, were reported by one subject only. The physical neurological examinations showed no signs of polyneuropathy such as paresis, hypaesthesia or pathological reflexes in any case. The findings of 1980 can thus be confirmed. ${ }^{19}$

Table 3 shows the results of the determinations of the nerve conduction velocity in the form of the

Table 3 Results of the nerve conduction velocity measurements in 10 PCP exposed workers in 1980 and 1984. The ranges and medians are shown. The nerve conduction velocity values are corrected for a skin temperature of $32^{\circ} \mathrm{C}$

\begin{tabular}{|c|c|c|c|c|}
\hline \multirow[b]{2}{*}{ Parameter } & \multirow[b]{2}{*}{ Nerve } & \multicolumn{2}{|c|}{ Nerve conduction velocity $\mathrm{m} / \mathrm{s}$} & \multirow{2}{*}{$\begin{array}{l}\text { Lower } \\
\text { value of } \\
\text { normal }\end{array}$} \\
\hline & & 1980 & 1984 & \\
\hline $\begin{array}{l}\text { MCV max } \\
\text { DSCV } \\
\text { DSCV } \\
\text { MCV max } \\
\text { DSCV }\end{array}$ & $\begin{array}{l}\text { Ulnar } \\
\text { Ulnar } \\
\text { Median } \\
\text { Peroneal } \\
\text { Sural }\end{array}$ & $\begin{array}{l}46-65(59) \\
40-50(46) \\
43-55(45) \\
- \\
-\end{array}$ & $\begin{array}{l}51-64(56) \\
38-52(50) \\
38-52(48) \\
49-63(58) \\
39-50(45)\end{array}$ & $\begin{array}{l}51 \\
40 \\
40 \\
45 \\
40\end{array}$ \\
\hline
\end{tabular}


ranges and medians for 1980 and 1984 . There were no significant changes in either the ranges or the medians. A delayed nerve conduction velocity due to age is not manifested, since this generally amounts to only about $1-2 \mathrm{~m} / \mathrm{sec}$ for one decade. ${ }^{23}$ Even considering the individual courses of the three neurophysiological parameters, no consistent or directional alterations are shown if a realistic interindividual variation of about $10 \%$ is taken as a basis. This is most evident for the sensory nervous conduction velocity of the median nerve, which is the measurement with the best reproducibility (fig 1 ).

To examine the presence of possible dose effect relations, we have plotted the sensory nervous conduction velocity of the median nerve and the sural nerve in relation to the exposure index (product of years of exposure and serum PCP concentration) (fig 2). This does not show a significant slowing of the nerve conduction velocity with increasing exposure.

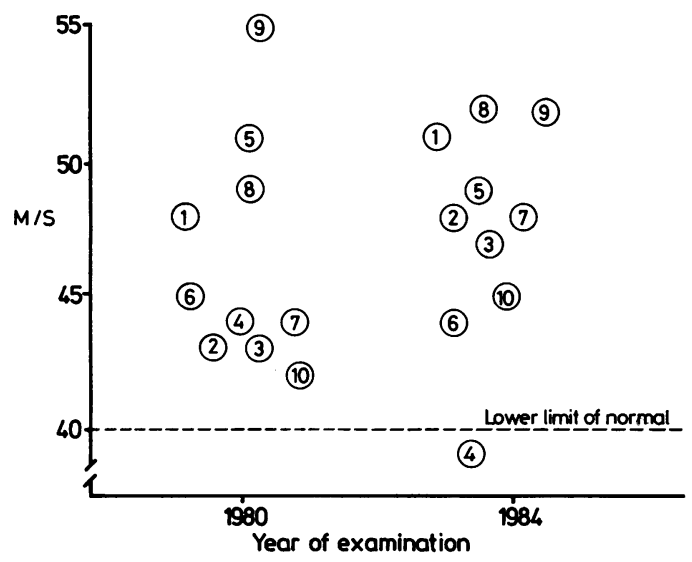

Fig 1 Individual sensory nerve conduction velocities of median nerve in 10 PCP exposed workers in 1980 and 1984.

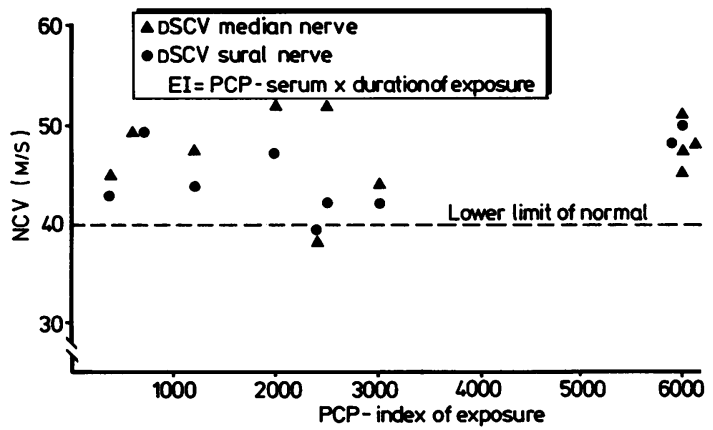

Fig 2 Individual sensory nerve conduction velocities of median and sural nerves of 10 subjects in relation to $P C P$ exposure index. (For details see text.)

\section{Discussion}

According to the knowledge available so far, the clin ical picture of chronic PCP intoxication is variable. If addition to symptoms affecting the central, periphe eral, and vegetative nervous systems, mucosal irri tations, alterations in the blood count, and hepato $\frac{}{5}$ toxic effects have been described. ${ }^{2-5}$ On the basis of recent reports, contaminations of technical PCE products by hexachlorodibenzodioxins, heptachlorodibenzodioxins, and octachlorodibenzodioxins should be discussed in addition to PCP as a cause fot the adverse health effects. ${ }^{24}$ In the air samples investigated tetrachlorophenols (TCP) could be detected at a level of up to $291 \mu \mathrm{g} / \mathrm{m}^{3}$. Tetra 3 chlorodibenzo-p-dioxin (TCDD), however, could not be detected in the technical PCP product (detection limit: $1 \mathrm{ppb}$ ). On the basis of these results, possible neurotoxic effects of TCDD could largely be rule $\mathscr{S}^{\circ}$ out. The chlorinated hydrocarbons lindan and aldrip could be detected only in traces up to $5 \mathrm{ppb}$ in ai samples, so that a relevant neurotoxic effect could nod result from this.

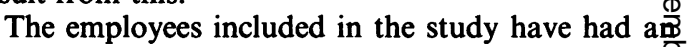
average of 16 years contact with working materialo containing TCP or PCP. A comparison of the results. of biological monitoring of the years 1980 and 18860 shows good agreements with regard to the serum $\mathrm{PEP}$ values. ${ }^{19}$ It is important in this connection that aler ations in the production technique have not bey made in past years, so that retrospectively one mas assume relatively constant exposure conditions in this period. Lauwerys suggests a urinary limit value o 1 $1 \mathrm{mg}$ free $\mathrm{PCP} / \mathrm{g}$ creatinine ${ }^{25}$; there was only one case bordering on this both in 1980 and in 1984, the othe values were always below the limit. We have not found a recommended limit value for PCP in serumo The evaluation of a biological tolerance value for working materials (BAT value) for PCP by the Com $\$$ mission of the German Research Society is at presents in preparation (tentative values: $1000 \mu \mathrm{g} \mathrm{PCP} / 1$ serun and $300 \mu \mathrm{g} \mathrm{PCP} / 1$ urine). ${ }^{26}$

In some cases values at the workplaces investigateक are considerably less than the current MAK value ${ }^{27}$ of $500 \mu \mathrm{g} \mathrm{PCP} / \mathrm{m}^{3}$ air. Because of the known per? cutaneous absorption of PCP, biological monitorin has a greater significance for the surveillance of exposed workers than ambient air monitoring. N

The neurophysiological findings do not show anyo negative effects of a chronic exposure to PCP for both 1980 and 1984 or over time. There are thus no rele ${ }^{\omega}$ vant indications for the presence of adverse effects ork the peripheral nervous system. This observation supported by the results of correlation analyses using the exposure duration and exposure index respectively. Overall, no correlations were calculated 
in the sense of dose effect relations. We have found no corresponding published neurophysiological studies for employees exposed to PCP. The longitudinal study essentially confirms the results of the earlier investigation. ${ }^{19}$ The indications for a correlation between the altered pattern of neurophysiological results and long term PCP exposure detected at that time in three out of 18 subjects cannot be confirmed in the longitudinal study.

The lack of any peripheral neurotoxicity of PCP shown by these results is also explained pathophysiologically. PCP is more readily soluble in water than other chlorinated hydrocarbons (hexachlorocyclohexane, for instance) and thus does not have a pronounced affinity for the high lipid tissues of the nervous system.

\section{References}

1 Comstock EG. Current literature on medical toxicology and a bibliography of pentachlorophenol. Clin Toxicol 1980; 16:531-9.

2 Rao KR. Pentachlorophenol. New York-London: Plenum Press, 1978.

3 Kunde M, Böhme C. Zur Toxikologie des Pentachlorphenols: Eine Obersicht. Bundesgesundheitsblatt 1978;21:302-10.

4 Ahlborg U, Thunberg TM. Chlorinated phenols: occurrence, toxicity, metabolism, and environmental impact. CRC Crit Rev Toxicol 1980;7:1-35.

5 Williams PL. Pentachlorophenol, an assessment of the occupational hazard. Am Ind Hyg Assoc J 1982;43:799-810.

6 Gray RE, Gilliland RD, Smith EE, Lockard VG, Hume AS. Pentachlorophenol intoxication: report of a fatal case with comments on the clinical course and pathologic anatomy. Arch Environ Health 1985;40:161-4.

7 Uhl S, Schmid P, Schlatter C. Pharmacokinetics of pentachlorophenol in man. Arch Toxicol 1986;58:182-6.

8 Grimm HG, Schellmann B, Schaller KH, Gossler K. Pentachlorphenolkonzentrationen in Geweben und Körperflüssigkeiten von Normalpersonen. Zentralbl Bakteriol Mikrobiol Hyg B 1981;174:77-90.

9 Grimm HG, Schaller KH, Valentin H. Aktuelle Ergebnisse zur Pentachlorphenol-Exposition in Arbeitswelt und Umwelt. Zeutralblatt für Arbeitsmedizin 1985;35:136-42.

10 Zober A, Schaller KH, Gossler K, Krekeler HJ. Pentachlorphenol und Leberfunktion: Eine Untersuchung an beruflich belasteten Kollektiven. Int Arch Occup Environ Health 1981;48:347-56.

11 Baxter RA. Biochemical study of pentachlorophenol workers. Ann Occup Hyg 1984;28:429-38.

12 Triebig G, Braune U. Neurotoxische Arbeitsstoffe: II. Gewerbliche Lösemittel und andere organische Stoffe. Eine Literaturübersicht der Jahre 1970 bis 1982. Zentralbl Bakteriol Hyg B 1983;178:207-58.

13 Baader EW, Bauer HJ. Industrial intoxication due to pentachlorophenol. Indian Journal of Medical Sciences 1951;20:286-90.

14 Baumann K, Behling K, Brassow HL, Stapel K. Occupational exposure to hexachlorocyclohexane. Int Arch Occup Environ Health 1981;48:165-72.

15 Seppäläinen AM, Vuojolahti P, Elo O. Reversible nerve lesions after accidental polychlorinated biphenyl exposure. Scand $J$ Work Environ Health 1985;11:91-5.

16 Singer R, Moses M, Valcuikas J, Lilis R, Selikoff IJ. Nerve conduction velocity studies of workers employed in the manufacture of phenoxy herbicides. Environ Res 1982;29:297-311.

17 Filippini G, Bordo B, Crenna P, Massetto N, Musicco M, Boeri R. Relationship between clinical and electrophysiological findings and indicators of heavy exposure to 2,3,7,8-tetrachlorodibenzodioxin. Scand $J$ Work Environ Health 1981;7:257-62.

18 Valentin H, Schaller KH. Was sind "adverse Effekte"? Arbeitsmed Sozialmed Präventivmed 1981;16:109-12.

19 Triebig G, Krekeler H, Gossler K, Valentin H. Untersuchungen zur Neurotoxizität von Arbeitsstoffen. II. Messung der motorischen und sensorischen Nervenleitgeschwindigkeit bei beruflich Pentachlorphenol-belasteten Personen. Int Arch Occup Environ Health 1981;48:357-67.

20 Gossler K, Schaller KH. Eine gas-chromatographische Methode zur quantitativen Bestimmung von Pentachlorphenol im Urin und Plasma. Fresenius Z Anal Chem 1978;290:111-2.

21 Bomhard A, Schaller KH, Triebig G. Capillar-GasChromatographie mit ECD- und MS-Detektion zur quantitativen Bestimmung von Pentachlorphenol im menschlichen Plasma und Harn. Fresenius $Z$ Anal Chem 1984;319:516-9.

22 Triebig G. Untersuchungen zur peripheren Neurotoxität von einigen Arbeitsstoffen. Arbeitsmed Sozialmed Präventivmed, Band 72, Stuttgart: Gentner, 1985.

23 Ludin HP. Praktische Elektromyographie. Stuttgart: Enke, 1981.

24 Daugherty RC. Human exposure to pentachlorophenol. In: Rao KR, ed. Pentachlorophenol. New York-London: Plenum Press, 1978:351-61.

25 Lauwerys RR. Industrial chemical exposure: guideline for biological monitoring. Davis: Biomedical Publications, 1983.

26 Schaller KH, Valentin H. Pentachlorphenol. In: Henschler D, Lehnert G, eds. Biologische Arbeitsstoff-Toleranz-Werte (BAT-Werte). Vorbereitung: Verlag Chemie, 1986.

27 Deutsche Forschungsgemeinschaft. $M A K-/ B A T-W e r t e$ Liste. Weinheim: Verlag Chemie, 1985. 